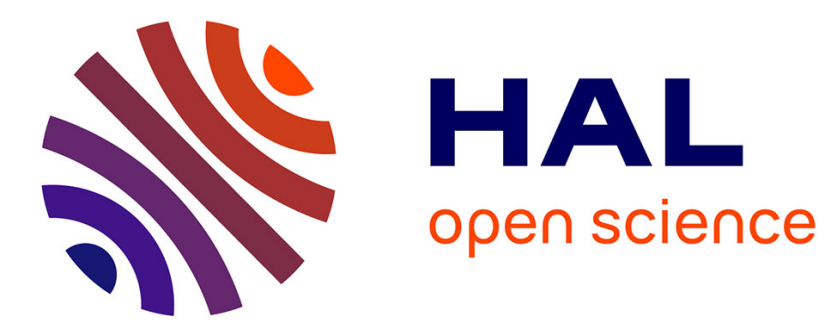

\title{
Sperm-triggered Calcium Oscillations at Fertilization
}

\author{
Alex Mcdougall
}

\section{To cite this version:}

Alex Mcdougall. Sperm-triggered Calcium Oscillations at Fertilization. The Biology of Ascidians, Springer Japan, pp.36-46, 2001, 10.1007/978-4-431-66982-1_7 . hal-03025773

\section{HAL Id: hal-03025773 \\ https://hal.science/hal-03025773}

Submitted on 16 Dec 2020

HAL is a multi-disciplinary open access archive for the deposit and dissemination of scientific research documents, whether they are published or not. The documents may come from teaching and research institutions in France or abroad, or from public or private research centers.
L'archive ouverte pluridisciplinaire HAL, est destinée au dépôt et à la diffusion de documents scientifiques de niveau recherche, publiés ou non, émanant des établissements d'enseignement et de recherche français ou étrangers, des laboratoires publics ou privés. 


\title{
Sperm-triggered Calcium Oscillations at Fertilization
}

\author{
Alex McDougall \\ Department of Physiological Sciences, Medical School, Framlington Place, University of \\ Newcastle upon Tyne, Newcastle upon Tyne, NE2 4HH, UK a.d.mcdougall@ncl.ac.uk
}

Summary. Reinitiation of embryonic development at fertilization is brought about by a sperm-triggered rise in egg cytosolic calcium $\left(\mathrm{Ca}^{2+}\right)$ levels. Three models of how sperm trigger this $\mathrm{Ca}^{2+}$ increase have been proposed: the conduit, contact and content models of fertilization. Overwhelming evidence indicates that the $\mathrm{Ca}^{2+}$-releasing second messenger inositol 1,4,5-trisphosphate $\left(\mathrm{InsP}_{3}\right)$ is produced at fertilization. The task ahead will be to determine how egg phospholipase $\mathrm{C} \gamma$ is activated at fertilization to generate $\mathrm{InsP}_{3}$. Although sperm trigger the initial $\mathrm{Ca}^{2+}$ rise in the egg, maternal factors determine whether the $\mathrm{Ca}^{2+}$ rise will be a solitary transient or else a series of oscillations. This is important since a solitary $\mathrm{Ca}^{2+}$ spike within physiological limits is not a sufficient stimulus for meiotic exit in ascidians. It is likely that the egg cyclin B-dependent kinase (Cdk1) activity determines whether the egg displays one $\mathrm{Ca}^{2+}$ transient or a series of $\mathrm{Ca}^{2+}$ oscillations; persistently elevated $\mathrm{Cdk1}$ activity prolongs the duration of sperm-triggered $\mathrm{Ca}^{2+}$ oscillations indefinitely. Partly because of this finding, but also since all the sperm-triggered $\mathrm{Ca}^{2+}$ oscillations are $\mathrm{Ca}^{2+}$ waves that display a predictable temporal pattern and spatial organisation, the ascidian has become an excellent testing ground for the various models of fertilization. Cytosolic extracts prepared from $A$. aspersa sperm injected into homologous eggs mimic fertilization using these three criteria: temporal pattern, spatial organisation, and regulation by egg Cdk1 activity. We therefore suggest that the content (sperm factor) model best explains fertilization in ascidians.

Key words. Fertilization, $\mathrm{Ca}^{2+}$ oscillations, $\mathrm{Cdk} 1$ activity, Content model

\section{Introduction}

Sperm reinitiate embryonic development at the moment of fertilization by triggering an increase in egg cytosolic calcium $\left(\mathrm{Ca}^{2+}\right)$ levels (Ridgeway et al. 1977; Steinhardt et al. 1977). In many animals these $\mathrm{Ca}^{2+}$ increases often take the 
form of oscillations (mammal: Cuthbertson et al. 1981; ascidian Speksnijder et al. 1989a; starfish: Stricker 1995; annelid: Eckberg and Miller 1995; mollusc: Deguchi et al. 1996; nemertean: Stricker 1996; reviewed by Sardet et al. 1998 and Stricker 1999). In both mammalian and ascidian eggs it has been demonstrated that $\mathrm{Ca}^{2+}$ oscillations are the trigger that reinitiates embryonic development (mammal: Kline and Kline 1992; ascidian: McDougall and Sardet 1995; Arnoult et al. 1996; Yoshida et al. 1998).

This review will address two issues. Firstly, how sperm initiate this $\mathrm{Ca}^{2+}$ rise in the egg - what molecules are involved? And secondly, how these $\mathrm{Ca}^{2+}$ oscillations are maintained by the egg and finally switched off at the end of meiosis when they are no longer required.

\section{Models of Fertilization}

For about a decade there have been three hypotheses of how sperm trigger $\mathrm{Ca}^{2+}$

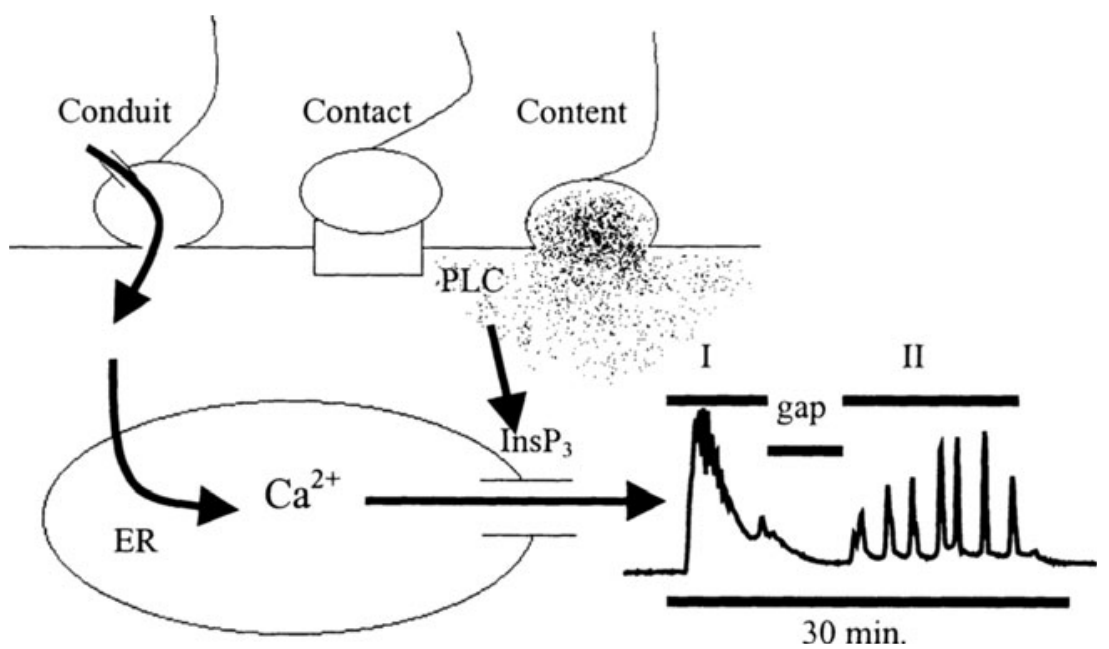

Fig. 1. Models of fertilization and the pattern of calcium oscillations displayed at fertilization in ascidians. Sperm are depicted interacting with the surface of the egg. The conduit model, contact model and content models are displayed. A typical calcium oscillation pattern at fertilization is also displayed (A.aspersa). The first and second phases of calcium oscillations (I and II) together with the gap are displayed (calcium oscillations are normally absent or are small during the gap (both phenomena are displayed here)). ER, endoplasmic reticulum, PLC, phospholipase C, InsP ${ }_{3}$, inositol 1,4,5trisphosphate. 